\title{
GCU
}

Glasgow Caledonian

University

University for the Common Good

\section{The contribution of rural businesses to community resilience}

\author{
Steiner, Artur; Atterton, Jane
}

Published in:

Local Economy

DOI:

$10.1177 / 0269094214528853$

Publication date:

2014

Document Version

Early version, also known as pre-print

Link to publication in ResearchOnline

Citation for published version (Harvard):

Steiner, A \& Atterton, J 2014, 'The contribution of rural businesses to community resilience', Local Economy, vol. 29, no. 3, pp. 228-244. https://doi.org/10.1177/0269094214528853

\section{General rights}

Copyright and moral rights for the publications made accessible in the public portal are retained by the authors and/or other copyright owners and it is a condition of accessing publications that users recognise and abide by the legal requirements associated with these rights.

Take down policy

If you believe that this document breaches copyright please view our takedown policy at https://edshare.gcu.ac.uk/id/eprint/5179 for details of how to contact us. 
The contribution of rural businesses to community resilience

Artur A Steiner and Jane Atterton, Scotland's Rural College

Corresponding author:

Artur Steiner, Land Economy and Environment Research Group, Scotland's Rural College, King's Buildings, Edinburgh, EH9 3JG, UK, Email: Artur.Steiner@sruc.ac.uk Telephone: 01315354387

\section{Abstract}

This paper explores the role of private sector enterprises in building the resilience of rural Scotland. In addition, the paper seeks to identify changes in rural enterprise activities and their impact on rural life. The paper is based on quantitative secondary data analysis and two qualitative case studies. These demonstrate how rural enterprises contribute to economic and social development in rural communities and the wider resilience of rural locations. Analysis of the secondary data highlights an increasing contribution by private sector enterprises to overall employment in rural Scotland. The data verifies the importance of SMEs and, in particular, micro-businesses in rural job creation. It also shows the role of rural businesses in increasing the diversification of the local economy and therefore in building wider rural community resilience. The results identify changing employment patterns in rural areas (such as an increasing level of self-employment, part-time and home-working and multiple job holding) which might be associated with the capacity to adapt to dynamic changes in the socioeconomic environment. Finally, qualitative findings help to further understand how private sector enterprises contribute to the social and environmental resilience of rural Scotland by identifying the 
role they play in enhancing the quality of life of those living in rural locations. Consequently, the paper makes a substantial and original contribution to existing knowledge and debate on resilience. It uses current data on the characteristics of rural private sector enterprises to identify their economic, social and environmental importance in building the resilience of rural places and their communities.

Keywords: Private Sector, Rural Resilience, Social and Economic Development, SMEs and microbusinesses

\section{Introduction}

In the UK and within its devolved administrations, there is an increasingly strong policy focus on developing the resilience of communities (Conservative Party, 2010a, 2010b; Cabinet Office, 2010a, 2010b; Scottish Government, 2007, 2010a). Drivers for this include the need to increase the efficiency of public sector spending, and to enhance self-reliance and sustainability at the community level. In addition to the challenging current economic climate, rural Scotland is going through a period of social transformation as a result of demographic shifts associated with migration and ageing patterns, globalisation, advances in communications technologies, new consumer preferences and demands. These processes have an impact on all community 'actors' including private enterprises, creating challenges but also new opportunities.

If the opportunities are harnessed and challenges overcome, private sector enterprises could help to build strong and resilient rural communities. Evolution or the adaptive capacity of enterprises and how they operate is, therefore, essential. This 'adaptive capacity' refers to the concept of resilience which is promoted in recent policy documents and to which we refer in this paper. 
The article explores the contribution of the private sector enterprises in the resilience of rural Scotland. It begins by providing information on the concept of resilience and the potential ability of private sector enterprises to maintain and enhance the resilience of rural communities. Following this, the research methods adopted in this study are described. Then, based on quantitative and qualitative data, the paper presents findings exploring the theme under investigation and highlighting the role of private businesses in rural resilience. Finally, the paper offers discussion and conclusions, including the key implications for researchers, policymakers and practitioners. Consequently, the paper (i) contributes to the current discussion about community resilience which is still in its early stage; (ii) is unique as it explores the role of private sector enterprises in building rural community resilience - thus linking knowledge in the field of entrepreneurship and resilience in a specific rural context, and (iii) it bridges evidence from international research and existing data from Scotland - a country in which policy is increasingly seeking to develop stronger and more resilient communities.

\section{Community resilience and the private sector}

Discussion about community resilience is evident in many recent research and academic papers (e.g. Pendall et al., 2010; Skerratt and Steiner, 2013; Steiner and Markantoni, 2013), community toolkits (e.g. Wilding, 2011; LEADER, 2010; Mguni and Bacon, 2010) and policy documents (e.g. Cabinet Office, 2011; Edwards, 2009; Scottish Government, 2010a). In spite of this increasing interest in this theme, there are key challenges in the current understanding of what community resilience is and how to achieve it. Although defining resilience is complex (Pendall et al., 2010), the term could be understood as the capacity of the system 'to absorb disturbance and re-organise while undergoing change so as to still retain essentially the same 
function, structure, identity, and feedbacks' (Folke, 2006, p.259). In the community scenario resilience is seen as 'the existence, development, and engagement of community resources by community members to thrive in an environment characterised by change, uncertainty, unpredictability, and surprise' (Magis 2010, p.402). Resilience is therefore more than maintaining given system characteristics. Rather, it includes the adaptive capacity of the system - it is the ability to adapt to stresses and changes and to transform into more desirable states. Thus, community resilience could be perceived as a continuous process which enables a community to thrive despite ongoing change in the socio-economic environment (Milman and Short, 2008).

When describing resilience, some researchers focus on social aspects (Aked et al., 2010; Hegney et al., 2008), while others focus on its economic characteristics (Magis, 2010; Noya and Clarence, 2009) and others on its environmental/ecological features (Adger et al., 2005; Milman and Short, 2008). Existing evidence suggests that, in order to develop community resilience it is necessary to possess earlier indicated adaptive capacity in the three dimensions including social, economic and environmental/ecological. Also, bringing together the different scales of resilience, it is argued that resilient communities consist of resilient groups and, within those groups, resilient individuals collaborating together (Hegney et al., 2008).

In order to be resilient, a community has to possess a resilient local economy i.e. economy with diverse businesses and employment opportunities (Bentley and Pugalis, 2013; Leach, 2013; Noya and Clarence, 2009). A diversified economy can help to achieve community wellbeing as it does not depend on just one industry. This means that during the economic downturn, in order to recover, community members can draw on a richer business portfolio. In rural areas, this might mean including value added products and diversified crops, within an agricultural system or diversified industries such as tourism sectors, energy production or 'knowledge-based' businesses that do not require physical presence in a city. 
To build resilient economies and develop economic prosperity, businesses should cooperate as well as compete. A diverse and innovative economy recognises the interdependency of businesses and the community and it focuses on how businesses and consumers can cooperate to keep money circulating within the community. According to Hegney et al. (2008, p.33) 'money spent and re-spent within the community builds more business, keeps more people employed, more services active in support of the community, and raises quality of life.' Vibrant private businesses can help to retain and attract further investments in the area and encourage population in-migration, which, in turn, contribute to growing private sector and increasing the resilience of rural economies and the communities that depend on them (Noya and Clarence, 2009). The strong inter-linking of rural businesses with households and communities (Jack and Anderson, 2002) means that the private sector plays a particularly critical role in maintaining vibrancy of rural areas and delivering essential products and services to their communities.

Private sector organisations can choose to engage community resources in a way that brings benefits to local communities. The engagement of local resources further develops and creates new resources increasing their productivity (Emery and Flora, 2006). This self-reinforcing cycle, in which community resources enable community objectives to be met, contributes to building community resilience which, thereafter, generates additional resources and capacity (Magis, 2010; Adger et al., 2005). This suggests that, by recognising and addressing community needs, private sector enterprises add to wider community resilience (Flora and Flora, 2004). We aim to verity this in the following part of this paper. 


\section{Methodology}

\section{Study context}

This paper focuses on rural areas of Scotland. Rural areas represent both: places of production and consumption (Woods, 2005). By meeting various production and consumption demands, private sector businesses generate employment and income and contribute to the diversification of rural economies. Rural private enterprises make an important contribution to the strength, sustainability and value-added of Scotland as a whole: overall, rural regions are estimated to account for over $25 \%$ of gross value added to the Scottish economy. This is substantial when it is considered that rural Scotland is home to only $18 \%$ of Scotland's population (Scottish Government, 2011a, 2011b). All these mean that rural areas of Scotland are vital in terms of national development and it is crucial to ensure their resilience in the age of globalisation and rapid socioeconomic change.

\section{Data sources}

The paper is based on quantitative secondary data analysis and two qualitative case studies. The former draws on a compendium of national statistics from a range of surveys and administrative databases presented in annual publications of Rural Scotland Key Facts (Scottish Government, 2008a, 2009, 2010b, 2011b, 2012). Rural Scotland Key Facts publications do not show change in the selected indicators over time but rather present data at one point in time. This article draws on Key Facts publications from several years to explore how rural businesses and employment patterns have evolved recently. This quantitative analysis of longitudinal data enables a verification of whether rural private businesses adapt to dynamic socio-economic changes in their environment. In addition, in order to map the density of private enterprises across Scotland, 
2011 Scottish Corporate Sector Statistics are used. The aim of using quantitative data is to explore whether private sector enterprises can contribute, at a national scale, to building more resilient rural communities.

To provide more in-depth information about the impact of activities undertaken by rural enterprises, two qualitative case studies are presented. The case studies were selected based on the following two criteria: (i) identified enterprises had to be located in rural Scotland, and (ii) they had to demonstrate their contribution to economic and social development in rural communities and the wider resilience of rural locations. The case studies aim to illustrate the ways in which private sector enterprises assist community development and to identify the potential impact of private sector enterprises on community resilience.

\section{Findings}

\section{Business density and business size}

Quantitative findings indicate that the highest density of businesses is in rural Scotland and, in particular, Orkney and Shetland Islands, Highland and Dumfries and Galloway (Figure 1). The Scottish Borders and Aberdeenshire also have a relatively high business density. The lowest proportion of private businesses is located in the 'Central Belt' (Scottish Government, 2011b). 
Figure 1: Density of enterprises per head of population (local authority level)

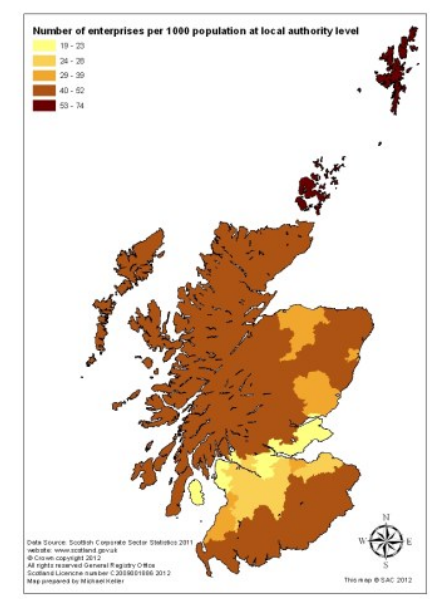

Figure 2 indicates that, proportionally, small enterprises dominate rural local authorities and medium and large enterprises are more characteristic of the urban areas in, or close to, the 'Central Belt' (Scottish Government, 2011b). A higher proportion of small enterprises in rural areas can be explained by the fact that small businesses represent an appropriate scale of activity for most rural economies. At the same time, it is important to acknowledge that some small rural enterprises serve global markets selling a unique product. The advantage of small businesses is that they can quickly adapt to changing socio-economic circumstances and customer demands. On the other hand, medium and large enterprises locate themselves near urban centres with easy access to the workforce, to a large customer base and to necessary large-scale infrastructure. 
Figure 2: Density of small, medium and large enterprises per local authority
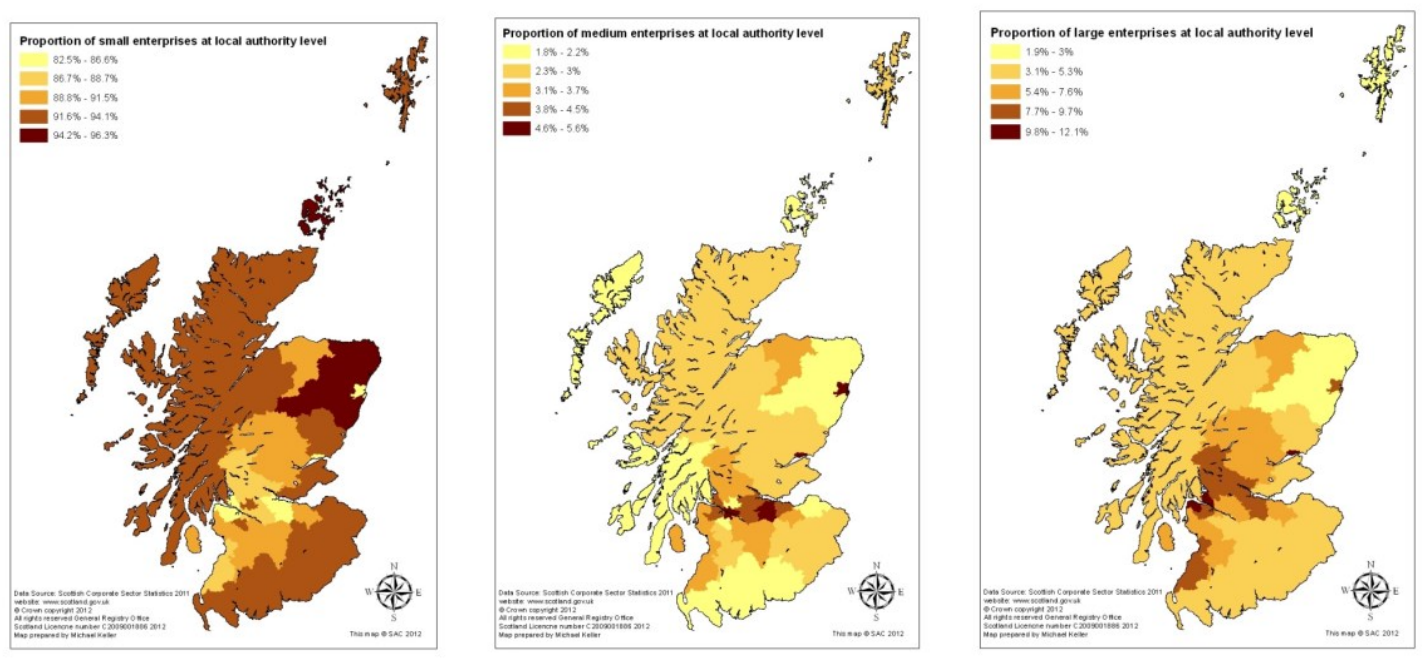

The role of micro, small, medium and large enterprises in employment provision

As presented in Figure 3, micro-enterprises (with 0-9 employees) appear to be the major employment provider in remote rural Scotland. While some micro and small enterprises in rural areas are providing niche products and services for consumption locally, others are producing small quantities of specialist products for global markets that are too small for mass producers (Atterton and Affleck, 2010). Large enterprises (with $250+$ employees), on the other hand, show the higher importance in terms of employment creation in urban centres. 
Figure 3: Employment by industry size in the private and in the public sectors by geographic area

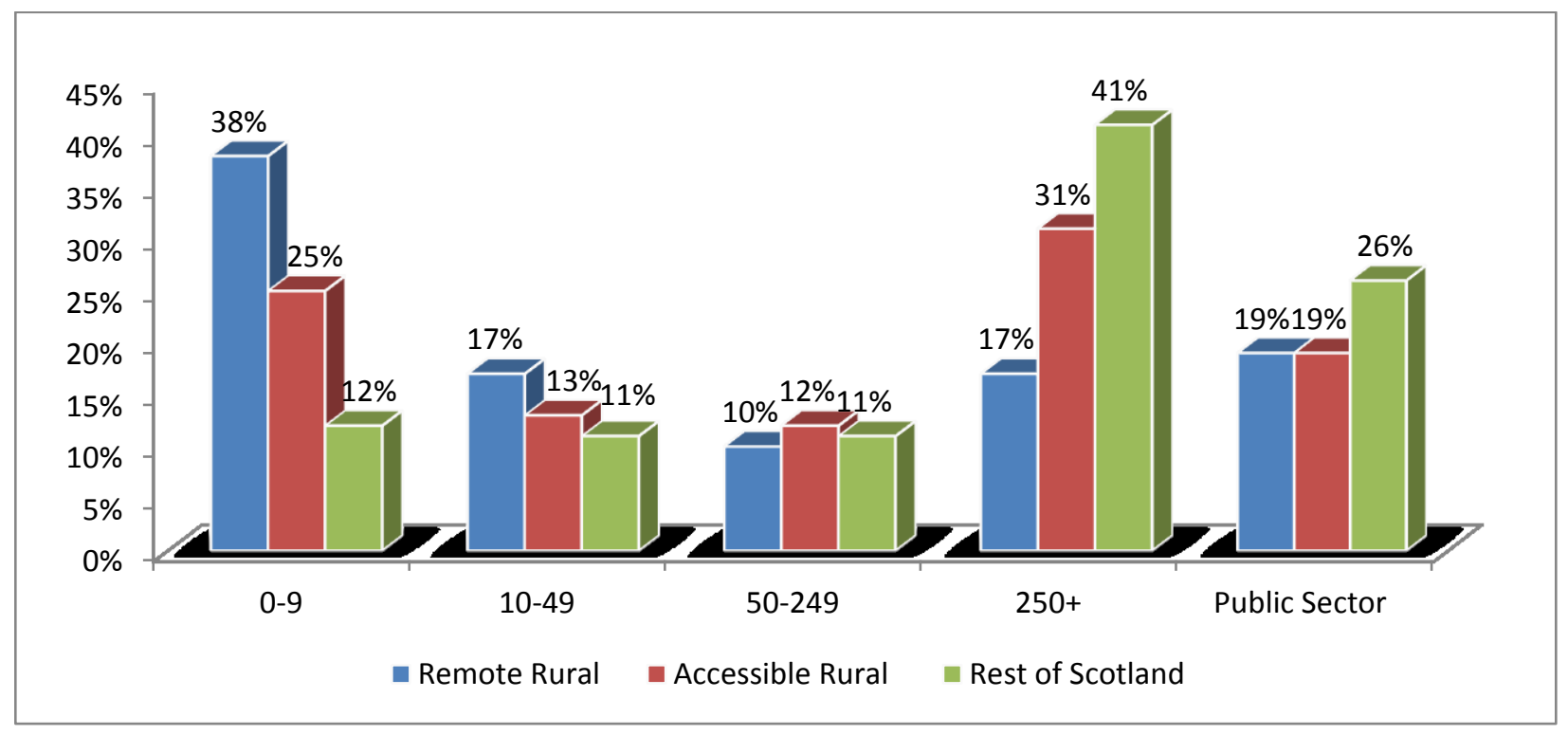

Source: Scottish Government, 2012

The fact that the highest proportion of micro and small enterprises is located in rural areas may suggest that people living in rural locations have entrepreneurial characteristics which encourage the creation of new businesses. Locally run businesses can help in building community resilience as the result of a number of factors. Firstly, local people know best about available local resources (Centre for Community Enterprise, 2000). Utilising those resources in a sustainable way brings benefits to community members and develops community resilience. Resources that are not utilised can decline and evaporate (Magis, 2010). Thus, private sector businesses, and in particular micro and small enterprises, are essential in bringing and developing the wealth of local communities. Secondly, as suggested in recent UK policy (Conservative Party, 2010a, 2010b; Scottish Government, 2007, 2010a), local people know best what their needs are and how those can be 
satisfied. Thus, micro and small businesses are important in identifying market gaps and addressing those by producing new goods/services. While doing this, local people take part in the process of empowerment in which community members (e.g. business owners) take an active role in self-development. Empowerment is an important element that helps to build resilient communities. Referred to as 'a process where people work together to make change happen in their communities by having more power and influence over what matters to them', being empowered helps communities to take control over what happens by taking collective action to make change possible (Scottish Community Development Centre, 2011, p.10). Thirdly, private sector businesses can contribute to diversified economies which are one of the essential components of resilient communities. An economy that does not depend on one industry can ensure that during a period of economic downturn, community impacts are less severe (Hegney et al., 2008). On the other hand, it could be argued that high numbers of businesses may reflect an absence of alternative employment opportunities leaving people forced to set up new enterprises as a means of generating an income. Although this might not be perceived as positive, it suggests that community members are not passive towards unfavourable factors in their environment. Instead, they are proactive, adapt to their local environment and identify initiatives which can solve their problems (Steinerowski and Steinerowska-Streb, 2012). This 'proactiveness' is another characteristic of resilient communities.

\section{Changing working patterns in rural Scotland}

Access to employment is important in raising the economic resilience of a place and therefore contributing positively to community resilience. Better jobs, increased levels of entrepreneurship, business performance and sustainability are indicators of resilience (Noya and Clarence, 2009). However it is important to analyse how and where people work in remote and rural Scotland and whether the private sector offers a variety of 
employment opportunities. Data indicates increasing levels of self-employment, part-time working, and home working in remote rural Scotland (see Figure 4). As such, in remote rural areas $22 \%$ of the workforce is selfemployed, compared to $18 \%$ in accessible rural areas and $10 \%$ in the rest of Scotland. It is worth noting that the proportion of self-employed people in rural Scotland is twice as much as in the rest of Scotland. This could refer to already mentioned entrepreneurialism and/or 'proactiveness' of rural citizens.

The findings indicate that between 2007 and 2011, the number of people in part-time employment increased across Scotland, but especially in rural areas (Scottish Government, 2008a, 2009, 2010b, 2011b, 2012). There is no evidence on the extent to which those working part-time do so due to their lifestyle or necessity. However, research has found that some rural businesses (often those in the tourism or arts and crafts sectors) are referred to as 'lifestyle businesses'. This reflects the fact that owners are motivated to set up their business to achieve a more positive work/life balance, take on a new challenge, develop a personal interest or exploit a market opportunity (Atterton and Affleck, 2010). This ability of rural community members who wish to work less hours and take advantage of 'generated' free time refers to equally important social aspects of resilience such as increased level of happiness, increased level of self-esteem and wellbeing (Aked et al., 2010; Schor 2010). Thus, part-time work, if represented as a life-choice style, contributes to the resilience of people in rural communities. Alternatively, if the part-time employment is a result of a lack of full-time employment opportunities or an absence of public transport or childcare services (i.e. is not a result of individual choice), this characteristic might be perceived as not desirable. Interestingly, and in relation to the latter, rural Scotland has a higher proportion of people who have a second job. Although evidence is not widely available on the extent to which individuals are taking on second jobs through choice or necessity, the data shows that rural private sector enterprises offer additional or alternative employment. These patterns could be perceived as 'adaptation patterns' which are essential in creating sustainable communities (Magis, 2010). 
Another important feature of employment in rural Scotland is home-working. Findings show that between 2007 and 2011, the proportion of people working from home has increased, particularly in remote rural areas (5\%). Taking into consideration the short time-span of this change, it presents a substantial shift in workpatterns. This suggests that rural business owners adapt to changing circumstances and, for example, take advantage of improvements in technology and base their business at home. Further improvements in broadband connectivity in rural areas may increase the number of those working from home and encourage more private sector enterprises to diversify into, or set up, new businesses that use opportunities offered by a modern technology. New technology and home-working might, therefore, present an option to those wishing to stay and live in rural Scotland. This, consequently, can help to retain those in working age in rural locations contributing to a 'healthy demographic balance' in communities. Moreover, these trends may have wider implications, including reducing the negative environmental impacts associated with long commuting journeys, generating additional local economic activity and providing a flexible employment option for those with caring responsibilities. Finally, home-working adds to diversified employment opportunities offering communities a wider choice of jobs. 
Figure 4: Changing types of employment from 2007 to 2011 by geographic area

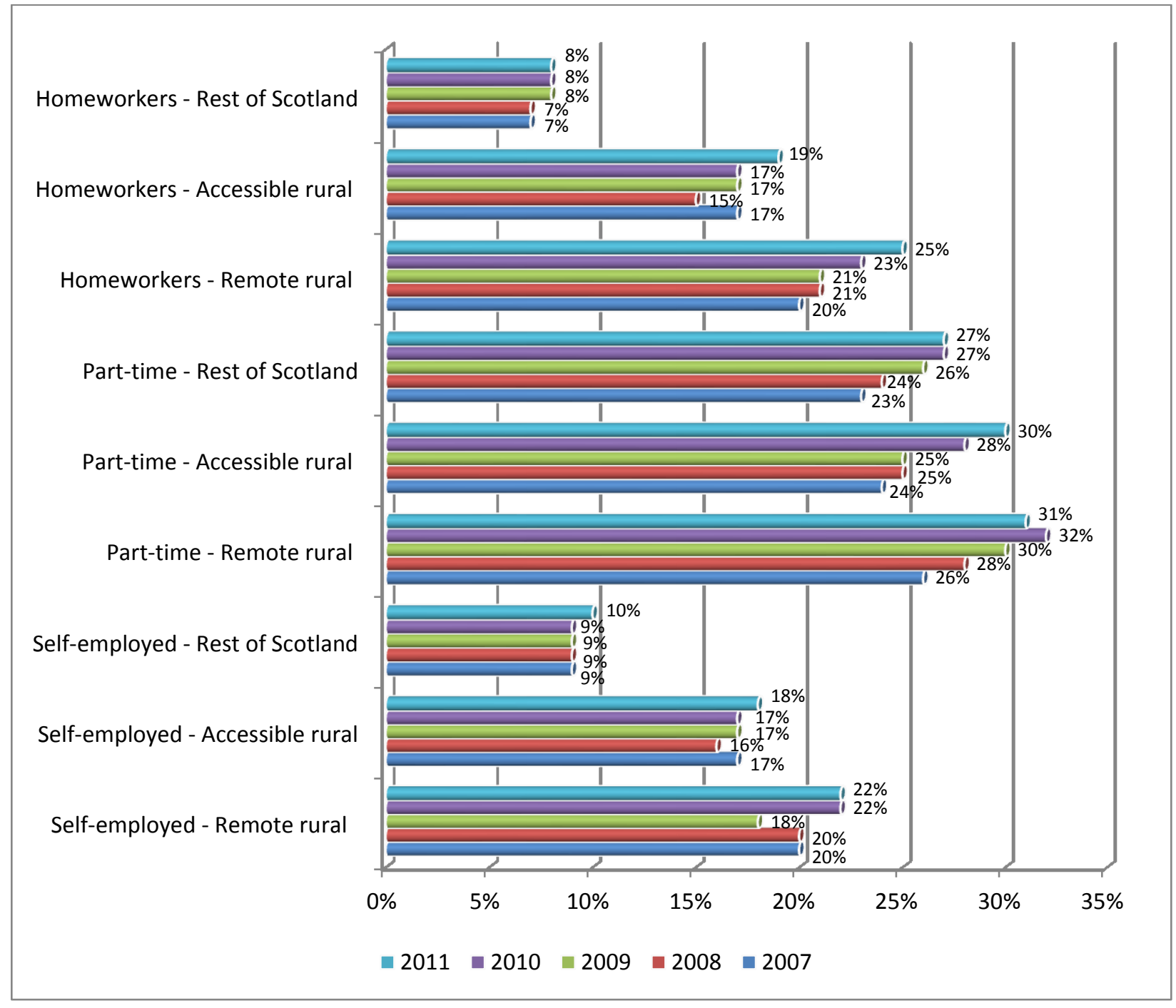

Source: Scottish Government 2008a, 2009, 2010b, 2011b, 2012 


\section{Employment diversity in rural Scotland}

Community members with diversified complementary skills can act as facilitators in community development, building stronger and more resilient communities (Wilding, 2011; Hegney et al., 2008). In order to develop and maintain skills within an area, a range of businesses offering different career paths are needed. In recent years, many rural areas - particularly more accessible rural areas - have experienced a diversification of their economic structures away from a traditional dependence on primary sector activities such as agriculture and fishing (FSB, 2008). These are presented in Figure 5.

Figure 5: Sectoral employment in 2011

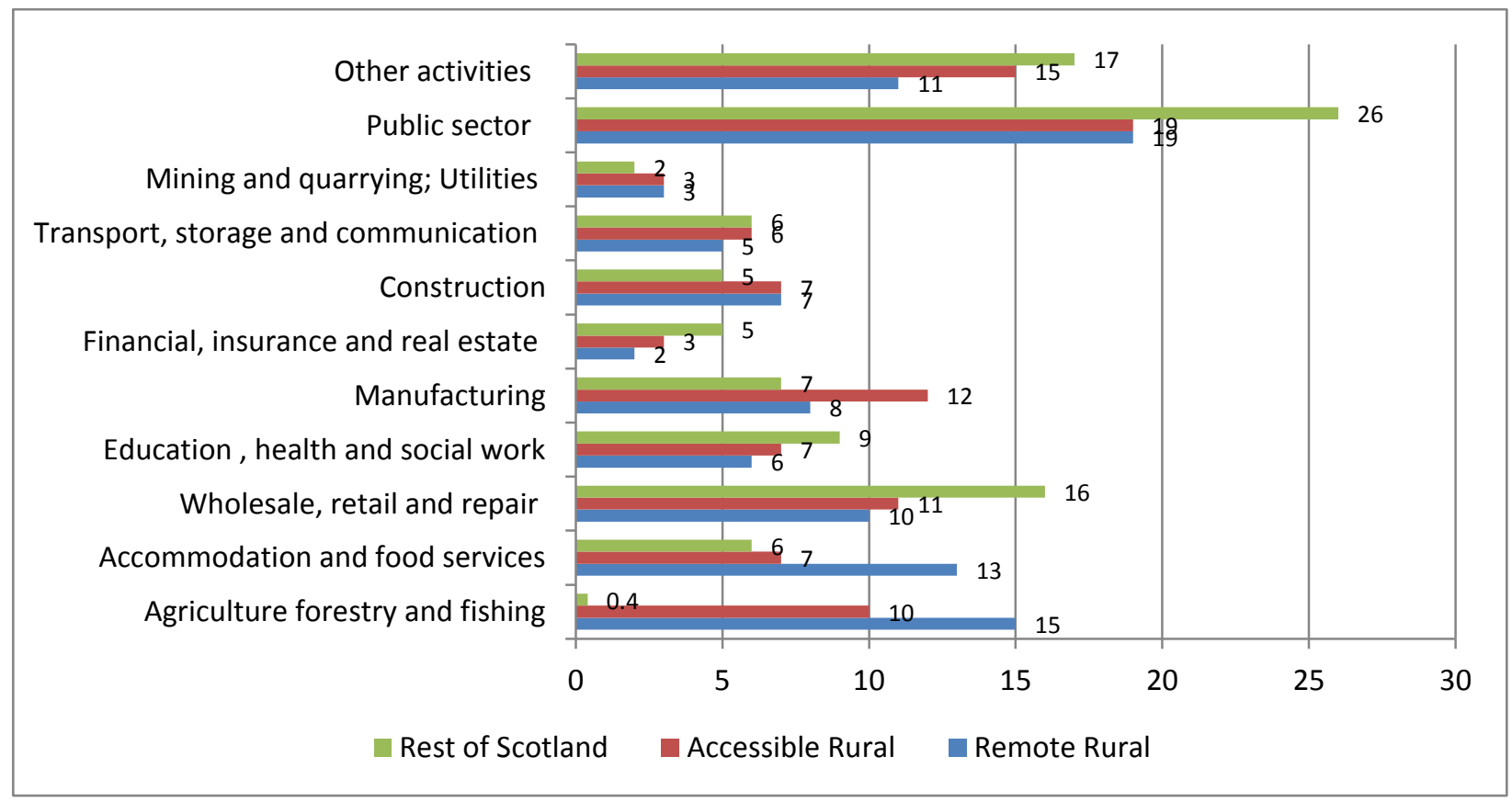

Source: Scottish Government 2012 
Evidence suggests that rural businesses undertake diversified activities harnessing Scotland's natural resources including producing niche, value-added food products, leisure, catering and tourism services and renewable energy generation. In addition to developing 'digitalised' business opportunities which offer new prospects to rural businesses, their owners and wider rural communities, it is anticipated that the role of the private sector will be critical in helping to utilise Scotland's natural resources and in contributing to meeting low carbon objectives set up by the Scottish Government (2010c). Renewable energy projects can bring substantial benefits, including sustainable income and job creation in rural areas. They can also bring benefits that remain in the local area for the community, for example, through upskilling local people to take advantage of new job opportunities, through securing local investment in infrastructure, services, the environment and cultural projects and through tackling social challenges such as fuel poverty (Atterton et al., 2011b). There are other potentially less tangible outcomes too, such as increasing community confidence and community empowerment - factors building resilience of communities (Scottish Community Development Centre, 2011; Scottish Government, 2010a). Thus, increasing employment diversity created by private sector enterprises contributes to resilience of individual and their communities.

These adaptation trends, such as an increasing level of home-working or diversified private sector industries, have an impact on employment levels. Over the recent years, and due to the economic crisis, unemployment in Scotland increased from 4.2\% in 2008 to $8.6 \%$ in 2011 (Scottish Government, 2008b; Scotland Office, 2012). However, in 2011, unemployment in both remote and accessible Scotland was lower than the national average (Scottish Government, 2011b, 2012). 
Figure 6: Unemployment rates between 2007 and 2011 by geographic area in Scotland

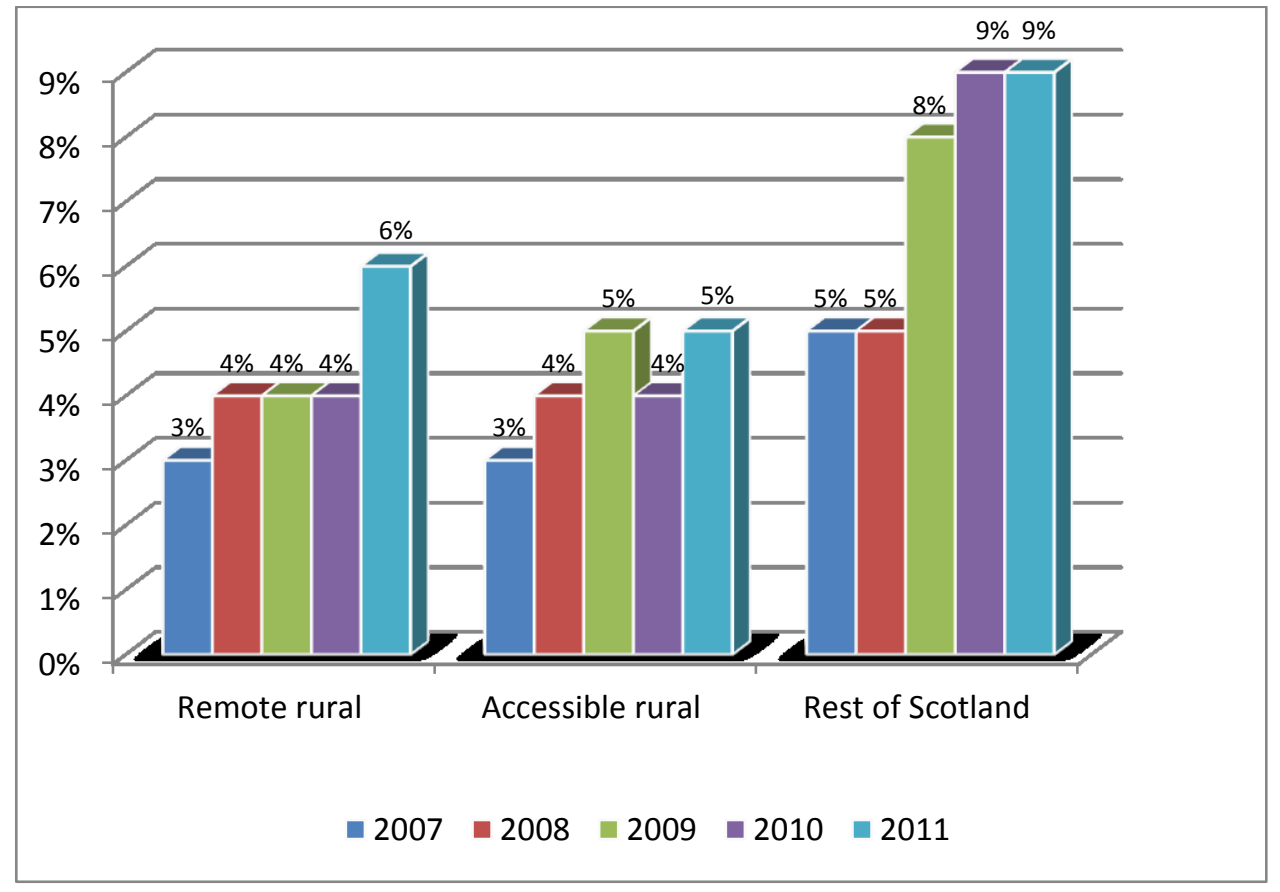

Source: Scottish Government, 2008a, 2009, 2010b, 2011b, 2012

The data (Figure 6) suggests that rural residents are less likely to be unemployed which may imply that rural economies are more resilient and capable of adapting to the current economic challenges. This is because unemployment levels in rural areas have risen by lower rates between 2007 and 2011, than in the rest of Scotland. Possibly, the characteristics of rural private businesses - in that they adapt more quickly to changing circumstances and therefore re-shape and take a different form (e.g. home-working) - help them to survive 
and provide continuous employment. If this is the case, the activities of rural private businesses relate to one of the key components of resilience i.e. adaptive capacity.

There might be, however, other reasons which help to understand why rural enterprises perform, in employment terms, better than businesses located in the rest of Scotland. Evidence suggests that rural businesses are more closely tied into their local communities demonstrating considerable loyalty to their local area (Farmer et al., 2008). This is particularly the case for businesses that are serving local markets or that are relying on local suppliers (Atterton et al. 2011a; Atterton 2007; Chell and Baines 2000). This, for example, is demonstrated in the strong overlapping or embeddedness of economic and social relationships and ties in rural areas (Jack and Anderson, 2002). This close relationship may assist the rural private sector in remaining more resilient during different economic times.

\section{Socially and environmentally friendly private enterprises}

The following case studies illustrate the contributions that rural businesses make - both individually and collectively - to enhancing the economic, social and environmental resilience of rural areas.

Case study 1 - Cream o' Galloway was founded in 1994 with the vision of creating and retaining employment within a rural area in an ethical and sustainable way. Diversification of the farm into the manufacture of ice cream and an environmentally aware visitor attraction has generated 19 full-time permanent and 35 seasonal jobs. Five jobs in the farming business have been maintained. Implementing the innovation and diversification enabled the achievement of economic growth and wider community benefits: in addition to creating local jobs, the company creates volunteering opportunities and organises events that help people to increase their awareness of their environmental impact. The farm also has environmental education 
programmes for local schools. Over the recent years, the business owners have worked closely with the local community, especially in relation to the development of the community wind turbine which was developed on the Cream o' Galloway farm in 2008. The energy produced is used on site for ice cream manufacture. The company also pays the local community for the electricity consumed, with that community income then used for match funding for community projects. In the future, the company owners plan to generate $40 \%$ of their electricity from on farm renewable sources. Cream o' Galloway's contributes to the recognition of the region and attracts tourist to come to the area: the company's visitor centre welcomes around 70,000 visitors annually. By selling its products throughout Scotland, England, and in South Korea the company contributes to the recognition of the region.

Business collaboration and the resilience of local supply chains

Case study 2 - Savour the Flavours was created by businesses in Dumfries and Galloway, with help from LEADER and Dumfries and Galloway Council. Savour the Flavours is an umbrella group responsible for promoting produce from the region. It aims to deliver a stronger and more robust food and drink industry in Dumfries and Galloway and its members include farmer producers, food manufacturers, retailers and delicatessens, farmers markets, hotels and chefs. The main activities of Savour the Flavours are business support and development, linking suppliers and local channels to market, and marketing Dumfries and Galloway to the consumer as a source of excellent food and drink and education.

One of the key benefits that Savour the Flavours brings to Dumfries and Galloway is building stronger networks between those producing high quality produce and outlets such as restaurants, hotels and delicatessens. Local producers are therefore able to successfully target the consumer by combining efforts and jointly investing in the future. Savour the Flavours also organises Flavour Fortnight, a region-wide food 
festival which is designed to raise awareness and understanding of the high quality local food products available in the region. Events such as this bring large numbers of visitors to the region as well as attracting local people.

Both case studies present local private sector enterprise initiatives that contribute to economic, social and environmental resilience through providing employment, generating income for the local area, supporting the education and training of local residents, and investing in renewable energy. This highlights how private sector organisations can choose to use business resources and engage community resources in a way to bring benefits to local communities which, according to Magis (2010, p.402) is essential in building community: resilience that is 'the existence, development, and engagement of community resources by community members to thrive in an environment characterized by change, uncertainty, unpredictability, and surprise'.

\section{Discussion}

The data presented in this paper suggests that rural businesses contribute to building the resilience of rural Scotland. They do that in direct and indirect ways. In the former, there is a clear link between the activities of rural businesses and the resilience of rural communities. This might relate to 'traditional' functions of the businesses such as employment creation and service/product delivery. An indirect impacts on community resilience, on the other hand, is a consequence of direct activities. For instance, growing and diversifying the private business sector can help to maintain the working-age population in a local area contributing to the 'demographical balance' and thus support local (public, private and third sector) service provision. It can also 
utilise and develop existing resources increasing the quality of life and wellbeing of rural residents, increasing the attractiveness of a place as a tourism destination and improving community cohesion

Quantitative data has showed that private sector enterprises are the major employer in rural Scotland and proportionally they generate more jobs per head of population than private businesses in the rest of Scotland. The data reveals that the importance of rural private enterprises in generating employment has grown over the recent years. It is an important finding as it suggests that rural private sector enterprises adapt to a quickly changing environment and the increasingly unfavourable economic climate of recent years. This conclusion is supported by other work which has argued that rural businesses may be more resilient and adaptable than their urban counterparts during challenging times, particularly due to the close intertwining of businesses and households (see for example, Phillipson et al. 2004; Oughton et al., 2003).

The data presented here also demonstrates that, at a time of rising national unemployment, rural areas have managed to keep their relatively high employment level providing jobs to their residents. While to some extent this positive message may be a result of the out-migration of people who are unemployed to urban centres to find work, the data also suggests that rural labour markets demonstrate flexibility in difficult times, with residents able to take on seasonal, contract, part-time or even self-employment work when full-time jobs are scarce, rather than remaining unemployed (see also Green, 2006). Of course, not all of these employment options may be taken up through choice, with some people forced into changing their employment situation if a preferred full-time option is not available. These patterns highlight that more research work is needed on the patterns of employment in rural Scotland, particularly during periods of economic downturn.

Nevertheless, evidence suggests that Scotland's rural areas have a higher business density than the rest of Scotland. Although businesses tend to be small, the data showed the importance of micro and small 
businesses in providing employment to rural residents. As it is easier for small enterprises to respond to changing business circumstances, it could be argued that this high proportion of micro and small businesses in rural Scotland enables a quick adaptation process, or a 'transition', that helps rural businesses and their communities to perform well and maintain/enhance their resilience. This flexibility is also important as it enables rural private businesses to better meet the changing needs of communities. On the other hand, existing large businesses can offer, for example, training opportunities, a wider range of career paths and large investments.

Our findings also revealed the changing characteristics of the private sector in rural Scotland including aspects such as self-employment, part-time and home working, and multiple job-holding. Changes in the indicated dimensions might be an answer to both threats and opportunities in the rural business sector, by avoiding or minimising threats and harnessing opportunities, rural businesses support development and innovation (including in terms of ways of working, for example). They also engage with new industries which present opportunities for both businesses and wider communities. The latter means that businesses located in rural areas are operating in an increasingly wide range of sectors. Some of the developments have been enabled by improvements in information communications technology and the availability of new business units. Diversified businesses not only help to provide a wider range of services and products but, in addition, create more stable local economies which is especially important in the period of economic downturn. This has an impact on community wellbeing.

In addition to the quantitative findings, qualitative data presented an interesting insight into how rural businesses can support their communities and contribute to their resilience. In one example, in order to survive and to generate additional local employment, and a range of other benefits for local residents, a 
family-owned farm has diversified its business activities. The case study shows that due to the strong interconnecting of rural businesses, households and communities, rural private enterprises help to adapt to changes in socio-economic environment. The second case study, on the other hand, presented a rural business jointworking initiative which focuses on encouraging collaborative working and partnership between local businesses to respond quickly to opportunities and to be more competitive and sustainable. The latter helped to develop close working relationships based on mutual trust and respect. As well as being creative and innovative, this collaboration of rural businesses facilitated better use and sharing of available resources in the local area. Both case studies show how rural businesses, and collaboration between them, bring economic, social and environmental benefits to rural communities, and, in consequence, build the resilience of rural Scotland.

The quantitative and qualitative findings illustrate another important aspect in terms of the existence of individual and community resilience. Individual resilience might be enhanced, for example, by a sufficient number of existing employment opportunities, diversity of jobs and career patterns. Community resilience, on the other hand, could be developed though diversified businesses delivering a range of products and services that are essential for wellbeing of communities. Individual and community resilience are interlinked and an increase in both dimensions of resilience occur in parallel. This suggests that in order to enhance community resilience, it is important to build resilience of individuals and, at the same time, the resilience of individuals can build upon community resilience. 


\section{Conclusions}

Building on the evidence presented, this paper helps to better understand the contribution of the rural private sector to the resilience of rural Scotland. As indicated, businesses in rural Scotland have an important role to play in contributing to the wider regional and national economy. A strong private sector brings a range of economic benefits to rural communities and, possibly more importantly, positive social and environmental outcomes. Thus, rural private sector enterprises bring direct and indirect benefits some of which might be difficult to measure.

The identified changing characteristics of rural businesses are associated with dynamic socio-economic changes in the current environment. Data presented in this article indicates that one of the roles of the private sector enterprises is to enhance rural community resilience. They do that through their adaptive capacity and the ability to adapt to stresses and changes. Rural private sector enterprises help to transform rural communities into more sustainable and vibrant places. This 'adaptive capacity' means that they are important in shaping and re-shaping the lives of rural citizens.

As current UK and Scottish policies support the development of resilient communities, governments at all levels need to recognise the substantial contributions that rural private enterprises make to building the economic, social and environmental resilience of rural places and their communities. Currently, these broad contributions are not well recognised through traditional measures such as economic growth, productivity, gross value added and competitiveness. New techniques and measures are required to better understand the impact of the rural private sector in maintaining and increasing rural population levels, maintaining a high quality environment, increasing quality of life and wellbeing and/or supporting local service provision. National policies may, therefore, need to be tailored to best support rural businesses and to further enhance 
the role they can play in building resilience of rural areas. This might be increasingly important if, due to the current political and economic climate, the public sector contracts and those moving out seek private sector employment or to set up their own business.

The paper contributes to current academic knowledge relating to community resilience by showing that economic and social resilience are not separate components of resilience but are complementary. Strengthening economic resilience enables increase in social resilience. Progress in one of the areas brings progress in the other one; consequently, if economic resilience declines, social resilience is also likely to decline. This raises important issues for researchers and practitioners interested in resilience: (i) Researchers who explore rural community resilience should acknowledge the contribution of rural businesses, and rural employment patterns more generally, to building more resilient communities - or even to undermining community resilience. When measuring and evaluating resilience, both social and economic dimensions should be considered. Links could also be made between research focusing specifically on aspects of resilience to broader research exploring notions of 'neo-endogenous' or 'networked' rural development, in which the 'success' of rural communities is argued to be dependent on the development of local resources (including human capital, the local stock of businesses, natural resources and land) - and local control over those resources and how they used - but the existence of networks and partnership relationships that extend beyond the local community to diverse partners and layers of government (Shucksmith, 2012). (ii) Practitioners, who often focus on social resilience aspects, should not underestimate the role of private sector enterprises. Rural businesses and those that support them, on the other hand, need to recognise that their enterprises bring a range of benefits to their communities. 


\section{Acknowledgments}

This research took place within the Scottish Government-commissioned Strategic Research Programme, "Governance and Decision-Making for Community Empowerment" (2011-2016). The authors would like to thank Cream o' Galloway and Savour the Flavours for their contributions.

\section{References}

Adger NW, Hughes TP, Folk C, Carpenter SR and Rockstron J (2005) Social-ecological resilience to coastal disasters. Science 309(5737):1036-1039.

Aked J, Marks N, Cordon C and Thompson S (2010) Five ways to wellbeing. The New Economics Foundation. Available at: http://neweconomics.org/projects/five-ways-well-being (accessed 10 April 2010).

Atterton J (2007) The strength of weak ties: Social networking by business owners in the Highlands and Islands of Scotland. Sociologia Ruralis 47(3):228-245.

Atterton J and Affleck A (2010) Rural Businesses in the North East of England: Final Survey Results (2009).

Centre for Rural Economy Research Report, Newcastle University.

Atterton J, Newbery R, Bosworth G and Affleck A (2011a) Rural enterprise and neo-endogenous development, in Alsos GA, Carter S, Ljunggren E and Welter F (Eds.) The Handbook of Research on Entrepreneurship in Agriculture and Rural Development, Edward Elgar, Cheltenham, UK, pp.256-280.

Atterton J, Woolvin M and Steinerowski A (2011b) On- and off-shore renewables: who benefits?, SAC Rural Policy Centre. Available at: 
http://www.sac.ac.uk/ruralpolicycentre/publs/changinenvironment/renewablesbenefits/ (Accessed 19

December 2012).

Bentley G and Pugalis L (2013) New directions in economic development: Localist policy discourses and the Localism Act. Local Economy 28(3):257-274.

Cabinet Office (2010a) The Coalition: Our programme for government. HM Government, London.

Cabinet Office (2010b) Building the Big Society, Cabinet Office. Available at:

http://www.cabinetoffice.gov.uk/media/407789/building-big-society.pdf (Accessed 30 October 2011).

Cabinet Office (2011) Strategic National Framework on Community Resilience, Cabinet Office. Available at: http://www.cabinetoffice.gov.uk/sites/default/files/resources/Strategic-National-Framework-on-CommunityResilience_0.pdf(Accessed 19 March 2012).

Centre for Community Enterprise (2000) The community resilience manual - A resource for rural recovery and renewal - the community resilience manual. CEE Publications, Port Alberni, Canada.

Chell E and Baines S (2000) Networking, entrepreneurship and micro-business behaviour. Entrepreneurship and Regional Development. 12:195-215.

Conservative Party (2010a) Big Society, Not Big Government: Building a big Society. Conservatives, London. Conservative Party (2010b) Invitation to join the government of Britain. Conservative Manifesto, London.

Edwards C (2009) Resilient Nation, London, Demos. 
Emery M and Flora C (2006) Spiraling-up: Mapping community transformation with community capitals framework. Journal of Community Development and Society 37(1):19-35.

Farmer J, Steinerowski A and Jack S (2008) Starting social enterprises in remote and rural Scotland: best or worst of circumstances? International Journal of Entrepreneurship and Small Business 6(3):450-464.

Flora C and Flora J (2004) Rural communities: Legacy and change (2nd ed.), Boulder, CO: Westview Press.

Folke C (2006) Resilience: the emergence of a perspective for social-ecological systems analyses. Global Environmental Change 16(3):253-267.

FSB (2008) A New Approach to the Rural Economy, Keep Trade Local. Federation of Small Businesses.

Green A (2006) Employment and the older person in the countryside, in Speakman L and Lowe P (Eds.) The Ageing Countryside: The Growing Older Population of Rural England. Age Concern Books: UK.

Hegney D, Ross H, Baker P, Rogers-Clark C, King C, Buikstra E, Watson-Luke A, McLachlan K and Stallard L (2008) Building Resilience in Rural Communities, The University of Queensland and University of Southern Queensland.

Jack SL and Anderson A (2002) The effects of embeddedness on the entrepreneurial process. Journal of Business Venturing 17(5):467-487.

Leach K (2013) Community economic development: Localisation, the key to a resilient and inclusive local economy? Local Economy 0(0):1-5. 
LEADER (2010) Building Resilient Communities - Good Practice Guide. LEADER, Dumfries \& Galloway, Scotland.

Magis K (2010) Community resilience: an indicator of social sustainability. Society and Natural Resources $33: 401-416$.

Mguni N and Bacon N (2010) Taking the temperature of local communities - The Wellbeing and Resilience Measure. London, The Young Foundation.

Milman A and Short A (2008) Incorporating resilience into sustainability indicators: An example for the urban water sector. Global Environmental Change 18(1):758-767.

Noya A and Clarence E (2009) Community capacity building: fostering economic and social resilience. CFE/LEED, OECD.

Oughton E, Wheelock J and Baines S (2003) Micro-businesses and social inclusion in rural households: a comparative analysis. Sociologica Ruralis 43(4):331-348.

Pendall R, Foster KA and Cowell M (2010) Resilience and regions: Building understanding of the metaphor, Cambridge Journal of Regions, Economy and Society 3(1):71-84.

Phillipson J, Bennett K, Lowe P and Raley M (2004) Adaptive responses and asset strategies: the experience of rural micro-firms and Foot and Mouth Disease. Journal of Rural Studies 20:227-243.

Schor JB (2010) Plenitude: The New Economics of True Wealth, Penguin Press. 
Scotland Office (2012) January Labour Market Statistics for Scotland. Available at:

http://www.scotlandoffice.gov.uk/scotlandoffice/16482.html (Accessed 20 September 2012).

Scottish Community Development Centre (2011) Community Resilience and Co-production - Getting to grips with the language, SCDC.

Scottish Corporate Sector Statistics (2011) A National Statistics publication on Scotland's business stock in 2011. Scottish Government, Available at: http://www.scotland.gov.uk/Publications/2011/10/SCSS11 (Accessed 24 May 2012).

Scottish Government (2007) Scottish Budget - spending review 2007., Edinburgh, Scottish Government. Scottish Government (2008a) Rural Scotland Key Facts 2008. People and Communities, Services and Lifestyle, Economy and Enterprise. A National Statistics Publication for Scotland, Edinburgh.

Scottish Government (2008b), “Scottish Economic Statistics”. Available at: http://www.scotland.gov.uk/Publications/2009/01/29150444/80 (Accessed 12 March 2012).

Scottish Government (2009) Rural Scotland Key Facts 2009. People and Communities, Services and Lifestyle, Economy and Enterprise, A National Statistics Publication for Scotland, Edinburgh.

Scottish Government (2010a) Rural Community Empowerment in the $21^{\text {st }}$ Century: Building a 'Can-Do'

Culture. Scottish Government, Available at: http://www.esrc.ac.uk/_images/Seminar_Report_25_Mar_10_ tcm8-2575.pdf (Accessed 28 April 2011).

Scottish Government (2010b) Rural Scotland Key Facts 2010. People and Communities, Services and Lifestyle, Economy and Enterprise. A National Statistics Publication for Scotland, Edinburgh. 
Scottish Government (2010c) Towards a Low Carbon Economy for Scotland: Discussion Paper. Scottish Government, Edinburgh.

Scottish Government (2011a) Renewing Scotland: The Government's Programme for Scotland 2011-2012. Scottish Government, Edinburgh.

Scottish Government (2011b) Rural Scotland Key Facts 2011. People and Communities, Services and Lifestyle, Economy and Enterprise, A National Statistics Publication for Scotland, Edinburgh.

Scottish Government (2012) Rural Scotland Key Facts 2012. People and Communities, Services and Lifestyle, Economy and Enterprise. A National Statistics Publication for Scotland, Edinburgh.

Shucksmith M (2012) Future Directions in Rural Development. Carnegie UK Trust.

Skerratt S and Steiner A (2013) Working with communities-of-place: complexities of empowerment. Local Economy 28(3):320-338.

Steiner A and Markantoni M (2013) Exploring Community Resilience in Scotland through Capacity for Change. Community Development Journal August:1-19.

Steinerowski A. and Steinerowska I (2012) Can social enterprise contribute to creating sustainable rural communities? Using the lens of structuration theory to analyse the emergence of rural social enterprise. Local Economy 27(2):167-182.

Wilding N (2011) Exploring community resilience in times of rapid change. Carnegie UK Trust.

Woods M (2005) Rural Geography. SAGE Publications, London. 